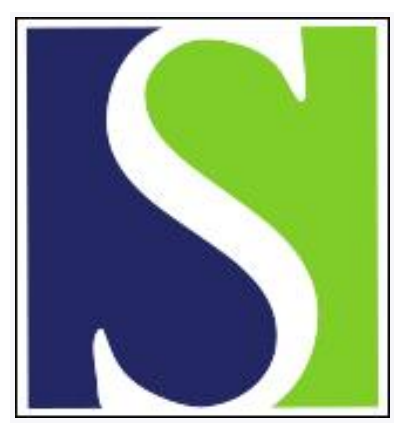

Scand J Work Environ Health 1985;11(4):249-255

https://doi.org/10.5271/sjweh.2223

Issue date: Aug 1985

The mortality of boot and shoe makers, with special reference to cancer.

by Pippard EC, Acheson ED

This article in PubMed: www.ncbi.nlm.nih.gov/pubmed/4059888

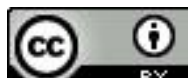




\title{
The mortality of boot and shoe makers, with special reference to cancer
}

\author{
by E Clare Pippard, MSc, ${ }^{1}$ E Donald Acheson, $\mathrm{DM}^{1}$
}

\begin{abstract}
PIPPARD EC, ACHESON ED. The mortality of boot and shoe makers, with special reference to cancer. Scand J Work Environ Health 11 (1985) 249-255. The study describes the mortality of 5017 men known to have been employed in the boot and shoe manufacruring industry in three towns in Great Britain in 1939. At the end of $1982,97.5 \%$ of the men were traced, and $3434(68.4 \%$ ) were known to be dead. Expected numbers were calculated according to the person-years method and were adjusted according to the standardized mortality ratios of the counties in which the towns were situated. The mortality experience of the men for all causes, all cancers combined, and all other causes was favorable. The anticipated excess of deaths from nasal cancer ( 10 observed, 1.87 expected) was found, and the excess was significant for workers in the finishing room. Deficits were found for other types of respiratory cancer. An excess mortality from leukemia was found for workers in one town (7 observed, 3.0 expected), and the excess was significant for workers in the lasting and making room, where glues and solvents, including benzene, were known to have been used. An excess mortality from rectal cancer was found for workers in two towns (61 observed, 47.6 expected), and it was significant for workers in the lasting and making rooms ( 25 observed, 12.4 expected). Some supporting evidence for a risk of rectal cancer in this industry was found in the literature.
\end{abstract}

Key terms: adhesives, chlorophenols, epidemiology, leather industry, leukemia, nasal and rectal cancer, solvents.

It has been shown in previous work that persons employed in the boot and shoe manufacturing and repairing industries who are exposed to the dust of leather soles and heels have a raised incidence of cancer of the nasal mucosa and accessory sinuses $(2,7)$. In the nickel refining and chromate industries the high risk of nasal cancer is associated with an increased risk of lung cancer $(6,12,13,15)$. Other studies have suggested an increased risk of leukemia $(14,27)$ and of cancers of the bladder $(9,10,28)$ and rectum (11) in shoe and leather workers. It was therefore decided to carry out a cohort study to investigate the risk of cancer in other sites of boot and shoe workers.

Since the 18th century the English shoemaking industry has grown in a number of distinct geographic areas, each traditionally known for different types of boots and shoes. Many different shoe companies are located in Northampton and its surrounding towns, an area which has always specialized in the manufacture of men's boots and shoes, particularly welted shoes. There is documentary evidence of an order for 5000 pairs of boots for the troops sent to Ireland by Parliament in 1642 (4). Stafford also had a large number of shoe factories in the past and, like Norwich and Leicester, was a traditional center for women's shoes. In contrast, the small town of Street

\footnotetext{
1 The Medical Research Council's Environmental Epide-
} miology Unit, Southampton, England.

Reprint requests to: Ms EC Pippard, MRC Environmental Epidemiology Unit, Southampton General Hospital, Southampton SO9 4XY, England. in Somerset owes its livelihood almost entirely to the boot and shoe industry which specializes in women's and children's shoes. Women's and children's shoes, apart from the heavier types, are rarely made with welts, as welting is an unsatisfactory way of making light shoes. Until the middle of the 19th century shoes were made almost entirely by hand, often in the homes of outworkers. The first machinery, which was introduced in the $1860 \mathrm{~s}$, led to the mass production of shoes in factories.

Because of the variation in the manufacturing processes in different parts of the country, it was decided to select cohorts of workers from three centers to examine the mortality of workers involved in all aspects of shoe production. The three centers chosen were Rushden in Northamptonshire (3 333 workers), Stafford (1 037 workers), and Street (647 workers), giving a total cohort of $5017 \mathrm{men}$. We describe the mortality of the three groups of male boot and shoe workers from 1939 to 1982 .

\section{Subjects and methods}

Using the National Health Service Central Register, staff of the Office of Population Censuses and Surveys searched the records of everyone resident in September 1939 in Rushden Stafford, and Street. They identified all men whose occupations at that time indicated that they were manufacturing boots and shoes. The vital status of these workers on 31 December 1982 was ascertained, and, in the case of those 
who had died, the date and cause of death were abstracted.

Information concerning the nature of the job done by each man was abstracted from the census records. No details on length of service in the industry were available. Over 900 different job titles were obtained in this way. These titles were classified by the Shoe and Allied Trades Research Association (SATRA) into five categories covering the main departments traditionally serviced by men in the shoe factories. These were clicking, lasting and making, finishing, operatives without a specified department, and men with other jobs (eg, mechanics and other tradesmen, managers, and men working in the smaller departments).

The number of deaths expected among these men was calculated according to the person-years method (20) and compared with the number observed. All deaths up to 31 December 1982 were included and five-year age-group cause-specific death rates for five-year calendar periods were used to calculate the expected numbers $(23,24)$. The rates used were for England and Wales as a whole. For table 3 an area correction was then incorporated into the analysis to adjust for local mortality during the years $1968-$
1978 (17). Tests of the statistical significance of the observed numbers of deaths compared with the expected number of deaths were based on the Poisson distribution.

The average age of the men in Rushden and Street in 1939 was 42 years, while in Stafford the workers' ages averaged 46 years.

\section{Results}

Almost all $(97.5 \%)$ of the men had been traced at the end of 1982, and $3434(68.4 \%)$ were known to be dead (table 1). A slightly higher proportion of men had died in Stafford than in Street and Rushden, presumably because of the difference in age already noted.

Table 2 shows the main causes of death for the period 30 September 1939 to 31 December 1982. The expected numbers have been calculated on the basis of national rates, and the standardized mortality ratios are given with $95 \%$ confidence limits. Presumably because of the relatively favorable health and social background of the men selected for this type of work, the mortality experience of the boot

Table 1. Male boot and shoe workers according to vital status on 31 December 1982, person-years of follow-up, and town.

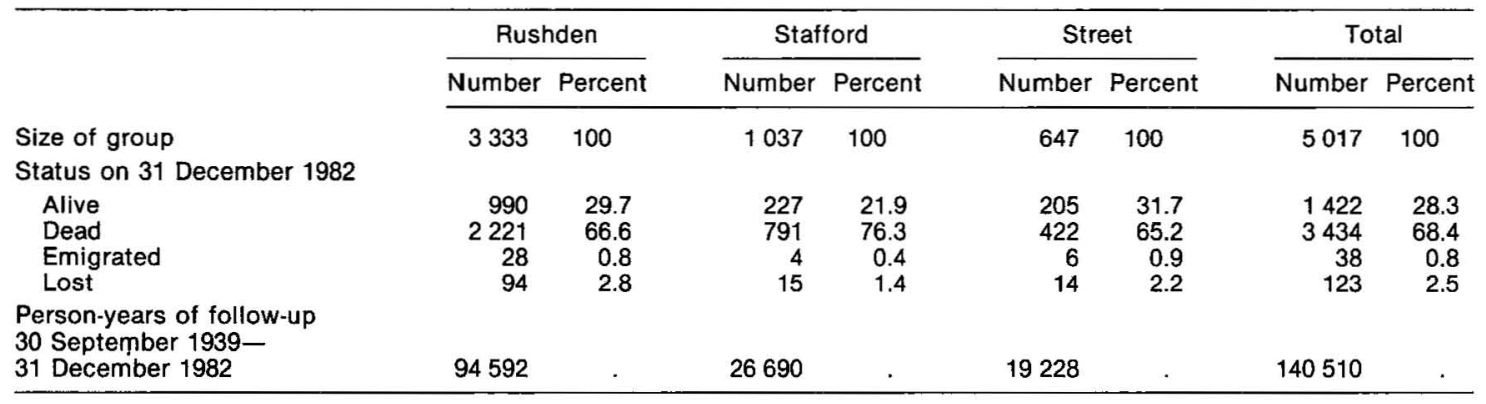

Table 2. Mortality of the male boot and shoe workers between 30 September 1939 and 31 December 1982 by town (Rushden, Street, and Stafford) in relation to the mortality of England and Wales.

\begin{tabular}{|c|c|c|c|c|}
\hline \multirow{2}{*}{ Cause of death } & \multicolumn{2}{|c|}{ Number of deaths } & \multirow{2}{*}{$\begin{array}{l}\text { Standardized } \\
\text { mortality } \\
\text { ratio }\end{array}$} & \multirow{2}{*}{$\begin{array}{l}95 \% \text { confidence } \\
\text { limits }\end{array}$} \\
\hline & Observed & Expected & & \\
\hline \multicolumn{5}{|l|}{ All causes } \\
\hline $\begin{array}{l}\text { Rushden } \\
\text { Street } \\
\text { Stafford }\end{array}$ & $\begin{array}{r}2221 \\
422 \\
791\end{array}$ & $\begin{array}{r}2829.4 \\
617.3 \\
864.4\end{array}$ & $\begin{array}{l}79^{*} \\
68^{*} \\
92^{*}\end{array}$ & $\begin{array}{l}75-82 \\
62-75 \\
85-98\end{array}$ \\
\hline Total & 3434 & 4311.2 & $80^{*}$ & $77-82$ \\
\hline \multicolumn{5}{|c|}{ All malignant neoplasms } \\
\hline $\begin{array}{l}\text { Rushden } \\
\text { Street } \\
\text { Stafford }\end{array}$ & $\begin{array}{r}428 \\
66 \\
147\end{array}$ & $\begin{array}{l}548.1 \\
119.7 \\
164.6\end{array}$ & $\begin{array}{l}78^{*} \\
55^{*} \\
89\end{array}$ & $\begin{array}{l}71-86 \\
43-70 \\
75-105\end{array}$ \\
\hline Total & 641 & 832.4 & $77^{*}$ & $71-83$ \\
\hline \multicolumn{5}{|c|}{ Causes other than malignant neoplasms } \\
\hline $\begin{array}{l}\text { Rushden } \\
\text { Street } \\
\text { Stafford }\end{array}$ & $\begin{array}{r}1793 \\
356 \\
644\end{array}$ & $\begin{array}{r}2281.3 \\
497.6 \\
699.9\end{array}$ & $\begin{array}{l}79^{*} \\
72^{*} \\
92^{*}\end{array}$ & $\begin{array}{l}75-82 \\
64-79 \\
85-99\end{array}$ \\
\hline Total & 2793 & 3478.8 & $80^{*}$ & $77-83$ \\
\hline
\end{tabular}

$* \mathrm{p}<0.05$. 
and shoe workers was better (significant at the $5 \%$ level) than the mortality of the general population for all causes combined, for all malignant neoplasms, and for all other causes combined in each of the three towns studied. The deficit of deaths from all malignant neoplasms in Stafford did not reach the $5 \%$ level of significance.
Table 3 presents the mortality by town for the principal sites of cancer. In this table, in addition to an expected number and an observed : expected ratio derived from national rates, the standardized mortality ratio (SMR) and $95 \%$ confidence limits are given, adjusted for the mortality of the relevant administrative county in which each town is situated.

Table 3. Mortality from cancer in male boot and shoe workers (30 September 1939-31 December 1982) by town (Rushden, Street, and Stafford). The standardized mortality ratios and $95 \%$ confidence limits have been adjusted for the administrative counties in which the towns are situated. (ICD = International Classification of Disease)

\begin{tabular}{|c|c|c|c|c|c|}
\hline \multirow{2}{*}{ Cause of death } & \multicolumn{3}{|c|}{ Number of deaths } & \multirow{2}{*}{$\begin{array}{l}\text { Standardized } \\
\text { mortality } \\
\text { ratio }\end{array}$} & \multirow{2}{*}{$\begin{array}{c}95 \% \text { confidence } \\
\text { limits }\end{array}$} \\
\hline & Observed (O) & Expected (E) & $O: E$ & & \\
\hline \multicolumn{6}{|c|}{ Cancer of the esophagus (ICD 150) } \\
\hline Rushden & 14 & 16.9 & 0.83 & 104 & $56-174$ \\
\hline Street & 1 & 3.6 & 0.28 & 31 & $1-173$ \\
\hline Stafford & 7 & 5.3 & 1.33 & 147 & $59-304$ \\
\hline \multicolumn{6}{|c|}{ Cancer of the stomach (ICD 151) } \\
\hline Rushden & 53 & 79.4 & 0.67 & $73^{*}$ & $55-96$ \\
\hline Street & 13 & 17.3 & 0.75 & 84 & $45-145$ \\
\hline Stafford & 22 & 24.8 & 0.89 & 78 & $49-118$ \\
\hline \multicolumn{6}{|c|}{ Cancer of the large intestine (ICD 153) } \\
\hline Rushden & 29 & 45.0 & 0.64 & $69^{*}$ & $46-99$ \\
\hline Street & 7 & 9.7 & 0.73 & 78 & $32-162$ \\
\hline Stafford & 18 & 14.2 & 1.27 & 123 & $73-195$ \\
\hline \multicolumn{6}{|c|}{ Cancer of the rectum (ICD 154) } \\
\hline Rushden & 46 & 36.1 & 1.27 & 136 & $99-181$ \\
\hline Street & 6 & 7.8 & 0.77 & 85 & $31-185$ \\
\hline Stafford & 15 & 11.5 & 1.31 & 127 & $71-210$ \\
\hline \multicolumn{6}{|c|}{ Cancer of the pancreas (ICD 157) } \\
\hline Rushden & 21 & 22.4 & 0.94 & 96 & $59-146$ \\
\hline Street & 2 & 4.9 & 0.41 & 40 & $5-146$ \\
\hline Stafford & 6 & 6.7 & 0.90 & 96 & $35-211$ \\
\hline \multicolumn{6}{|c|}{ Cancer of the nose (ICD 160) } \\
\hline Rushden & 8 & 1.2 & 6.52 & $a^{2 *}$ & $2.8-12.8$ \\
\hline Street & 1 & 0.3 & 3.78 & . & $0.1-21.0$ \\
\hline Stafford & 1 & 0.4 & 2.67 & . & $0.1-14.9$ \\
\hline \multicolumn{6}{|c|}{ Cancer of the larynx (ICD 161) } \\
\hline Rushden & 5 & 6.9 & 0.73 & 79 & $26-184$ \\
\hline Street & 1 & 1.5 & 0.67 & 75 & $2-421$ \\
\hline Stafford & 4 & 2.2 & 1.84 & 189 & $52-486$ \\
\hline \multicolumn{6}{|c|}{ Cancer of the lung (ICD 162,163$)$} \\
\hline Rushden & 122 & 180.9 & 0.67 & $74^{*}$ & $62-89$ \\
\hline Street & 10 & 40.1 & 0.25 & $32^{*}$ & $15-59$ \\
\hline Stafford & 31 & 51.8 & 0.60 & $68^{*}$ & $47-97$ \\
\hline \multicolumn{6}{|c|}{ Cancer of the prostate (ICD 185) } \\
\hline Rushden & 33 & 43.6 & 0.76 & $69^{*}$ & $48-97$ \\
\hline Street & 7 & 9.7 & 0.72 & 62 & $25-126$ \\
\hline Stafford & 11 & 13.2 & 0.83 & 93 & $47-166$ \\
\hline \multicolumn{6}{|c|}{ Cancer of the bladder (ICD 188) } \\
\hline Rushden & 20 & 24.4 & 0.82 & 84 & $51-130$ \\
\hline Street & 4 & $\begin{array}{r}24.4 \\
5.4\end{array}$ & 0.74 & $\begin{array}{l}04 \\
78\end{array}$ & $21-193$ \\
\hline Stafford & 8 & 7.3 & 1.10 & 122 & $53-241$ \\
\hline \multicolumn{6}{|c|}{ Leukemia (ICD 204-208) } \\
\hline Rushden & 3 & 10.4 & 0.29 & $30^{*}$ & $6-89$ \\
\hline Street & 2 & $\begin{array}{r}10.4 \\
2.3\end{array}$ & 0.88 & 84 & $10-302$ \\
\hline \multirow{2}{*}{\multicolumn{6}{|c|}{ All other }} \\
\hline & & & & & \\
\hline Rushden & & 80.9 & 0.91 & . & $0.7-1.1$ \\
\hline Street & 12 & 17.3 & 0.69 & i. & $0.4-1.2$ \\
\hline Stafford & 17 & 24.5 & 0.69 & : & $0.4-1.1$ \\
\hline \multicolumn{6}{|c|}{ All cancers (ICD 140-208) } \\
\hline Rushden & 428 & 548.1 & 0.78 & $82^{*}$ & \\
\hline Street & 66 & 119.7 & 0.55 & $62^{*}$ & $48-79$ \\
\hline Stafford & 147 & 164.6 & 0.89 & 94 & $79-111$ \\
\hline
\end{tabular}

a. = adjustment not sensible; see text.

${ }^{*} p<0.05$. 


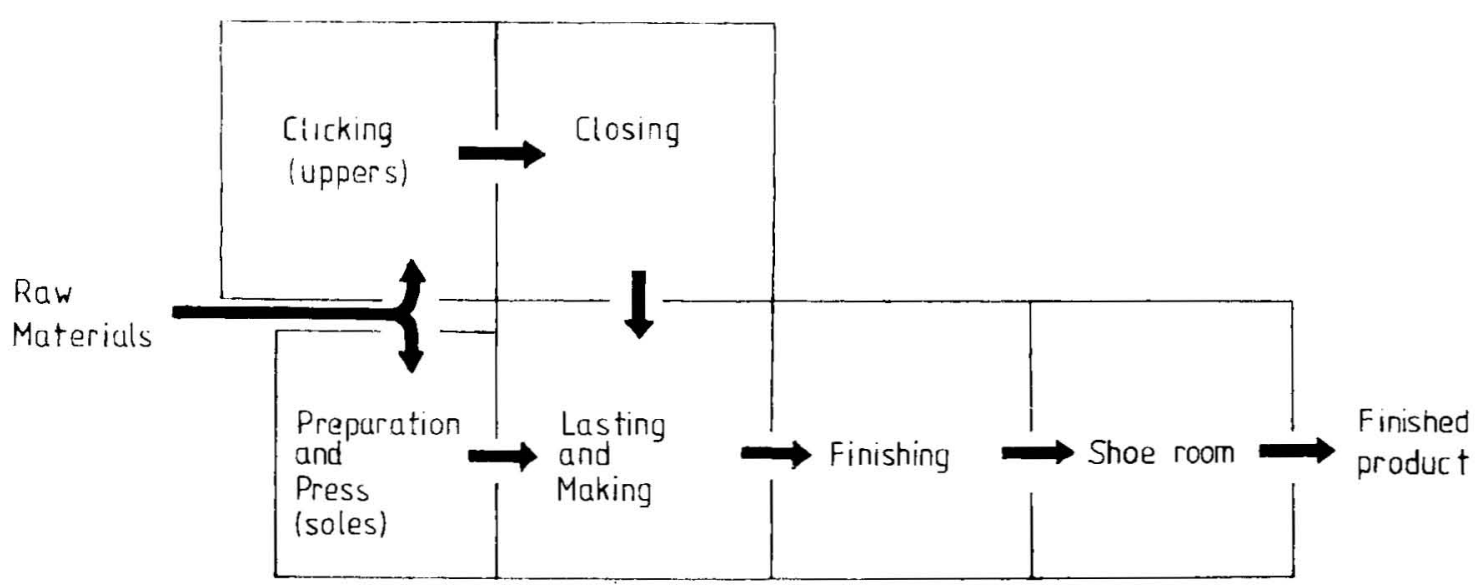

Figure 1. Plan showing the main departments of a typical shoe factory.

Table 4. Mortality from nasal cancer in boot and shoe workers (30 September 1939-31 December 1982) by factory department, in relation to the mortality of England and Wales.

\begin{tabular}{lcccc}
\hline Department & $\begin{array}{c}\text { Observed } \\
\text { deaths }\end{array}$ & $\begin{array}{c}\text { Expected } \\
\text { deaths }\end{array}$ & $\begin{array}{c}\text { Standardized } \\
\text { mortality ratio }\end{array}$ & $\begin{array}{c}95 \% \text { confidence } \\
\text { limits }\end{array}$ \\
\hline Clicking & 2 & 0.40 & 503 & $61-1818$ \\
Lasting and making & 2 & 0.51 & 393 & $48-1419$ \\
Finishing & 5 & 0.36 & $1408^{*}$ & $457-3286$ \\
Operatives without & - & 0.20 & - & $0-1816$ \\
specified department & 1 & 0.41 & 244 & $6-1359$ \\
Other men & 10 & 1.87 & $536^{*}$ & $257-985$ \\
\hline All departments & & & & 985 \\
\hline
\end{tabular}

$* 0<0.05$.

Ten nasal cancer deaths were observed, giving an overall relative risk of 5.4 (95\% confidence interval 2.6-9.9) based on an expected number derived from national rates. Although eight of these deaths occurred in workers from Rushden and one each occurred in a worker from Stafford and Street, the differences in relative risk are not statistically significant at the $5 \%$ level.

No increases in risk significant at the $5 \%$ level were found for any other cancer site, for the cohort as a whole or by town, whether on the basis of national or local rates. However, of the sites of cancer mentioned earlier as having possible associations with work in the boot and shoe or leather industries, excesses of rectal cancer in Rushden (SMR 136, $95 \%$ confidence limits 99-181) and Stafford (SMR 127, $95 \%$ confidence limits $71-210$ ) were noted. There was also an excess of leukemia among workers from Stafford (SMR 215, $95 \%$ confidence limits 86443), which was not significant.

Several causes of death showed significant deficits at the $5 \%$ level. Mortality from lung cancer was low in all three towns. Rushden also had significant deficiencies of leukemia, stomach cancer, and cancer of the large intestine according to both national and local standards of comparison, and for prostate cancer according to the local standard. In their study of
American shoeworkers, Decouflé and Walrath (11) found a significant excess of deaths from cancer of the liver and cancer of the gallbladder (combined). No such excess was seen in this study (17 deaths observed, 17.3 expected). Bladder cancer has also been associated with work in the shoe and leather industries $(9,10,28)$, but a deficit of deaths occurred from this cause in our present study ( 32 observed, $37.1 \mathrm{ex}$ pected). It has been suggested that exposure to chlorophenols may be important to the etiology of nasal cancer in leather workers (18) and sarcomas of connective tissue in other situations $(8,19)$. It is therefore of note that, although 1.59 deaths from cancers of connective and other soft tissue (International Classification of Disease 171) would have been expected, no deaths from this cause were recorded.

\section{Comparisons within the factories}

For sites where previous studies had been suggestive of an excess risk and for lung cancer we also examined the distribution of cases by factory department to see if a pattern related to a particular area of work emerged. For example, it is known from previous work $(2,7)$ that the excess risk of nasal cancer in this industry is limited almost exclusively to the preparation and finishing departments, boot and shoe fac- 
tories being divided into distinct departments (figure 1), each responsible for a different stage of shoe production.

The examination of the results by department can only be tentative because we have no occupational histories for the workforce other than the job being carried out on one day in September 1939. However, very little movement generally occurs within the factories, and this lack of movement is borne out by the results of examining the nasal cancer deaths by department (table 4 ). The mortality rate ratio estimate of nasal cancer of 14 in the finishing room is of the same order of magnitude as the rate ratio found in previous studies $(1,2)$.

A breakdown of the mortality from rectal cancer by department is shown in table 5 . Excesses are noted in the lasting and making departments of Stafford and Rushden (significant in Rushden) but not in Street. There were also excesses for operatives for whom there is insufficient information to determine the department, in Stafford (significant at the $5 \%$ level) and Rushden, and for other men (not significant) in Street. The likely hazardous exposures in the lasting and making room are to solvents, glues, and leather. No dyes, or colorants are used in this area (FB Blackwell, SATRA, personal communication).

An excess of deaths from leukemia occurred in the workers in one of the three towns (Stafford). Table 6 , which gives the breakdown of these deaths by department, shows that the excess is confined to the lasting and making room (significant at the $5 \%$ level). This is a department where exposure to solvents, including benzene, may have occurred $(3,27)$.

\section{Discussion}

The prime object of the study was to test the hypothesis that the known nasal cancer risk in boot and shoe

Table 5. Mortality from rectal cancer in boot and shoe workers (30 September 1939-31 December 1982) in the towns of Rushden, Street and Stafford, by factory department and in relation to the mortality of England and Wales.

\begin{tabular}{|c|c|c|c|c|}
\hline Department & $\begin{array}{l}\text { Observed } \\
\text { deaths }\end{array}$ & $\begin{array}{l}\text { Expected } \\
\text { deaths }\end{array}$ & $\begin{array}{l}\text { Standardized } \\
\text { mortality ratio }\end{array}$ & $\begin{array}{l}95 \% \text { confidence } \\
\text { limits }\end{array}$ \\
\hline \multicolumn{5}{|l|}{ Rushden } \\
\hline $\begin{array}{l}\text { Clicking } \\
\text { Lasting and making } \\
\text { Finishing } \\
\text { Operatives without }\end{array}$ & $\begin{array}{r}3 \\
20 \\
9\end{array}$ & $\begin{array}{r}7.70 \\
10.58 \\
7.54\end{array}$ & $\begin{array}{c}39 \\
189^{*} \\
119\end{array}$ & $\begin{array}{r}8-114 \\
116-292 \\
55-226\end{array}$ \\
\hline $\begin{array}{l}\text { specified department } \\
\text { Other men }\end{array}$ & $\begin{array}{l}7 \\
7\end{array}$ & $\begin{array}{l}4.28 \\
6.06\end{array}$ & $\begin{array}{l}163 \\
116\end{array}$ & $\begin{array}{l}66-337 \\
46-238\end{array}$ \\
\hline All departments & 46 & 36.14 & 127 & $93-170$ \\
\hline \multicolumn{5}{|l|}{ Street } \\
\hline $\begin{array}{l}\text { Clicking } \\
\text { Lasting and making } \\
\text { Finishing } \\
\text { Operatives without }\end{array}$ & $\frac{-}{-}$ & $\begin{array}{l}1.53 \\
1.87 \\
1.11\end{array}$ & $\overline{-}$ & $\begin{array}{l}0-242 \\
0-197 \\
0-332\end{array}$ \\
\hline $\begin{array}{l}\text { specified department } \\
\text { Other men }\end{array}$ & $\begin{array}{l}1 \\
5\end{array}$ & $\begin{array}{l}0.83 \\
2.42\end{array}$ & $\begin{array}{l}121 \\
207\end{array}$ & $\begin{array}{r}3-673 \\
67-482\end{array}$ \\
\hline All departments & 6 & 7.76 & 77 & $28-168$ \\
\hline \multicolumn{5}{|l|}{ Stafford } \\
\hline $\begin{array}{l}\text { Clicking } \\
\text { Lasting and making } \\
\text { Finishing } \\
\text { Operatives without }\end{array}$ & $\begin{array}{l}2 \\
5 \\
1\end{array}$ & $\begin{array}{l}2.12 \\
1.77 \\
2.24\end{array}$ & $\begin{array}{r}94 \\
283 \\
45\end{array}$ & $\begin{array}{r}11-341 \\
92-660 \\
1-249\end{array}$ \\
\hline $\begin{array}{l}\text { specified department } \\
\text { Other men }\end{array}$ & $\begin{array}{l}6 \\
1\end{array}$ & $\begin{array}{l}1.93 \\
3.41\end{array}$ & $\begin{array}{c}312^{*} \\
29\end{array}$ & $\begin{array}{r}114-678 \\
1-163\end{array}$ \\
\hline All departments & 15 & 11.45 & 131 & $73-216$ \\
\hline
\end{tabular}

$* p<0.05$.

Table 6. Mortality from leukemia in boot and shoe workers (30 September 1939-31 December 1982) in Stafford, by factory department and in relation to the mortality of England and Wales.

\begin{tabular}{|c|c|c|c|c|}
\hline Department & $\begin{array}{l}\text { Observed } \\
\text { deaths }\end{array}$ & $\begin{array}{l}\text { Expected } \\
\text { deaths }\end{array}$ & $\begin{array}{l}\text { Standardized } \\
\text { mortality ratio }\end{array}$ & $\begin{array}{c}95 \% \text { confidence } \\
\text { limits }\end{array}$ \\
\hline Clicking & 1 & 0.63 & 160 & $4-889$ \\
\hline Lasting and making & 3 & 0.53 & $566^{*}$ & $117-1653$ \\
\hline Finishing & - & 0.51 & - & $0-718$ \\
\hline $\begin{array}{l}\text { Operatives without } \\
\text { specified department }\end{array}$ & 1 & 0.39 & 254 & $6-1415$ \\
\hline Other men & 2 & 0.90 & 222 & $27-803$ \\
\hline All departments & 7 & 2.96 & 236 & $95-487$ \\
\hline
\end{tabular}

${ }^{\star} \mathrm{p}<0.05$. 
workers is associated with an increased risk of other respiratory cancers. As the nasal cancer risk is virtually confined to men because women shoe operatives do not generally undertake the dusty jobs involving sole leather and as the study had to be kept within a cost limit, we decided to restrict it to male workers. It should not therefore be assumed that women are not exposed to occupational hazards. In this industry women are traditionally employed in the shoe room where dyes and polishes are applied, so they may have an excess risk of bladder cancer. A significant excess of bladder cancer was found for female shoe workers (but not for men) in a study by Garabrant \& Wegman in Massachusetts (16). There was a deficit of deaths from bladder cancer in our study among the men.

The expected increased risk of nasal cancer was found and was largely confined to workers employed in the finishing department. Although the results were suggestive, it was not possible to demonstrate a significant difference in risk (chi square 1.3, 1 degree of freedom) between workers largely engaged in the manufacture of men's shoes (Rushden) and workers making women's shoes (Stafford and Street).

Large deficits of cases of lung cancer occurred in each town studied, and, except in Stafford, of laryngeal cancer (4 observed, 2.2 expected). Significant deficits of lung cancer remained even when local county death rates were used to calculate the expected numbers. Although we have no personal smoking data, it should be borne in mind that smoking is not permitted in the work areas of the factories. Nevertheless, in this study, there is no evidence of a lung or laryngeal cancer risk among boot and shoe workers.

The excess of rectal cancer is of interest because it was found in two of the three factories studied, predominantly. in the same department (the lasting and making room) in each. Excesses were also found for men for whom there was insufficient information to specify the work and who, therefore, might also have been employed in these departments.

There is some support for a relationship between rectal cancer and work in the boot and shoe industry in the literature. Decoufle \& Walrath (11) found a higher than expected mortality from rectal cancer among both male and female shoe workers in the United States but attributed this finding to local geographic factors. In a comprehensive study of the relationship between occupation and bowel cancer as a whole within the United States, Berg \& Howell (5) have demonstrated excesses among nonfactory shoe makers and repairers, operatives making leather and leather products, and in the footwear industry as a whole. They suggested that occupational exposure, possibly to solvents, dyes or metallic compounds, may account for this risk. The Registrar General's decennial supplements for England and Wales $(25,26)$ for 1961 and 1971 report standardized mortality ratios for rectal cancer for men aged 15-64 years in the 27 occupational orders. These data show that leather workers (occupational order IX) were one of 14 occupational orders with a standardized mortality ratio greater than 100 in both 1961 and 1971. This can therefore not be regarded as a specific finding.

During the period covered by our study, workers in the lasting and making departments of boot and shoe factories handled glues, the use of which resulted in exposure to solvents including benzene, carbon tetrachloride, trichloroethylene, and carbon disulfide. There is, to our knowledge, no known association between these substances and carcinoma of the rectum, although there is an unsubstantiated suggestion of an association between carcinoma of the colon and exposure to trichloroethylene (22).

An excess of leukemia deaths was noted for boot and shoe workers in Stafford ( 7 observed, 3 expected). Three of these deaths occurred in workers employed in the lasting and making department (SMR 566, $95 \%$ confidence limits 117-1 653). In Rushden two deaths from aplastic anemia occurred, both in young men (aged 24 and 26 years) employed in the lasting room. These cases seem likely to have been associated with exposure to benzene, but it was not possible to investigate the situation further.

The deficits of deaths from all causes, all malignant tumors, and other causes are probably due in part to the favorable areas of the country in which the factories are situated and also to the relatively socially favored groups from which the workforce are derived. This is particularly true of Street, where deficits were seen for all of the commonest sites of cancer. To be a boot and shoe maker in Street, in 1939 , meant working for the Clark family business. In the 19th century the Clarks, who were members of the Society of Friends (Quakers), impressed their ideals concerning, eg, tobacco and alcohol firmly on their workforce (21). It is to be conjectured that these circumstances may have been a factor in the good health of their workers.

\section{Acknowledgments}

This study would not have been possible without the help and cooperation of the staff at the National Health Service Central Register. We are also grateful for information on the boot and shoe industry obtained from Mr FB Blackwell at the Shoe and Allied Trades Research Association. We would like to thank Mr B Pannett for his industrial research and Mr P Winter for his help with the computing work.

\section{References}

1. Acheson ED. Nasal cancer in the furniture and boot and shoe manufacturing industries. Prev Med 5 (1976) 295-315. 
2. Acheson ED, Pippard EC, Winter PD. Nasal cancer in the Northamptonshire boot and shoe industry: Is it declining? Br J Cancer 46 (1982) 940-946.

3. Aksoy M, Erdem S, DinCol G. Leukaemia in shoeworkers exposed chronically to benzene. Blood 44 (1974) $837-841$.

4. Baynes K, Baynes K, ed. Shoe show: British shoes since 1790. Crafts Council, London 1979.

5. Berg JW, Howell MA. Occupation and bowel cancer. J Toxicol Environ Health 1 (1975) 75-89.

6. Bidstrup PL, Case RAM. Carcinoma of the lung in workmen in the biochromates-producing industry in Great Britain. Br J Ind Med 13 (1956) 260-264.

7. Cecchi F, Buiatti E, Kriebel D, Nastasi L, Santucci M. Adenocarcinoma of the nose and paranasal sinuses in shoe makers and woodworkers in the province of Florence, Italy (1939-77). Br J Ind Med 37 (1980) $222-225$.

8. Coggon D, Acheson ED. Do phenoxy herbicides cause cancer in man? Lancet 1 (1982) 1057-1059.

9. Cole P, Hoover R, Friedell GH. Occupation and cancer of the lower urinary tract. Cancer 29 (1972) 1250 1260 .

10. Decouflé P. Cancer risks associated with employment in the leather and leather products industry. Arch Environ Health 34 (1979) 33-37.

11. Decouflé $\mathbf{P}$, Walrath J. Proportionate mortality among US shoeworkers, 1966-1977. Am J Ind Med 4 (1983) 523-532.

12. Doll $\mathbf{R}$. Cancer of the lung and nose in nickel workers. Br J Ind Med 15 (1958) 217-223.

13. Doll R, Morgan LG, Speizer FE. Cancers of the lung and nasal sinuses in nickel workers. $\mathrm{Br} \mathrm{J}$ Cancer 24 (1970) 623-632.

14. Englund A. Cancer incidence among painters and some allied trades. J Toxicol Environ Health 6 (1980) $1267-1273$.

15. Enterline PE. Respiratory cancer amongst chromate workers. J Occup Med 16 (1974) 523-526.

16. Garabrant DH, Wegman DH. Cancer mortality among shoe and leather workers in Massachusetts. Am J Ind Med 5 (1984) 303-314.

17. Gardner MJ, Winter PD, Taylor CP, Acheson ED. Atlas of cancer mortality for England and Wales 1968-78. Wiley, Chichester 1983.

18. Hardell L, Axelson O, Rappe C. Nasal cancer and chlorophenols. Lancet 1 (1983) 1167.

19. Hardell L, Sandstrom A. Case-control study: Soft tissue sarcoma and exposure to phenoxyacetic acids or chlorophenols. Br J Cancer 39 (1979) 711-717.

20. Hill ID. Computing man years at risk. Br J Prev Soc Med 26 (1972) 132-134.

21. Lehane B. C and J Clark 1825-1975. C and J Clark Ltd, Street, Somerset 1975.

22. Merletti F, Heseltine E, Saracci R, Simonato L, Vainio $\mathrm{H}$, Wilbourn J. Target organs for carcinogenicity of chemicals and industrial exposures in humans: A review of results in the IARC monographs on the evaluation of the carcinogenic risk of chemicals to humans. Cancer Res 44 (1984) 2240-2250.

23. Office of Population Censuses and Surveys. Cancer mortality, England and Wales, 1911-70. Her Majesty's Stationery Office, London 1975.

24. Office of Population Censuses and Surveys. Cancer mortality in England and Wales, 1971-78. Her Majesty's Stationery Office, London 1980.

25. Registrar General. Decennial supplement for England and Wales 1961, occupational mortality tables. Her Majesty's Stationery Office, London 1971 .

26. Registrar General. Decennial supplement for England and Wales 1970-72, occupational mortality. Her Majesty's Stationery Office, London 1978.

27. Vigliani EC. Leukaemia associated with benzene exposure. Ann NY Acad Sci 271 (1976) 143-151.

28. Wynder EL, Onderdonk J, Mantel N. An epidemiological investigation of cancer of the bladder. Cancer 16 (1963) $1388-1407$.

Received for publication: 17 December 1984 